\title{
NHP2 Gene Mutation
}

National Cancer Institute

\section{Source}

National Cancer Institute. NHP2 Gene Mutation. NCI Thesaurus. Code C152082.

A change in the nucleotide sequence of the NHP2 gene. 